\title{
Effect of feeding a by-product feed-based silage on nutrients intake, apparent digestibility, and nitrogen balance in sheep
}

\author{
J. S. Seok, Y. I. Kim, Y. H. Lee, D. Y. Choi and W. S. Kwak ${ }^{*}$ (D)
}

\begin{abstract}
Background: Literature is lacking on the effects of feeding by-product feed (BF)-based silage on rumen fermentation parameters, nutrient digestion and nitrogen $(\mathrm{N})$ retention in sheep. Therefore, this study was conducted to determine the effect of replacing rye straw with BF-based silage as a roughage source on ruminal parameters, total-tract apparent nutrient digestibility, and $\mathrm{N}$ balance in sheep.

Methods: The by-product feed silage was composed of spent mushroom substrate (SMS) (45\%), recycled poultry bedding (RPB) (21\%), rye straw (11\%), rice bran (10.8\%), corn taffy residue $(10 \%)$, protected fat (1.0 \%), bentonite $(0.6 \%)$, and mixed microbial additive $(0.6 \%)$. Six sheep were assigned randomly to either the control (concentrate mix + rye straw) or a treatment diet (concentrate mix + BF-based silage).

Results: Compared with the control diet, feeding a BF-based silage diet resulted in similar ruminal characteristics ( $\mathrm{pH}$, acetate, propionate, and butyrate concentrations, and acetate: propionate ratio), higher $(p<0.05)$ ruminal $\mathrm{NH3}-\mathrm{N}$, higher $(p<0.05)$ ether extract digestibility, similar crude protein digestibility, lower $(p<0.05)$ dry matter, fiber, and crude ash digestibilities, and higher $(p<0.05) N$ retention $(g / d)$

Conclusion: The BF-based silage showed similar energy value, higher protein metabolism and utilization, and lower fiber digestion in sheep compared to the control diet containing rye straw.
\end{abstract}

Keywords: Spent mushroom substrate, By-product feed, Silage, Digestibility, Sheep

\section{Background}

Imported roughages such as rye straw, tall fescue hay, and timothy hay are expensive, however cheap, good quality silage can be developed using the feed ingredients which are abundant and easily available in many Asian countries. Previously in our laboratory the good quality by-product feed (BF)-based roughage was successfully manufactured by ensiling spent mushroom substrate (SMS), recycled poultry bedding (RPB), rice bran, and a minimal amount of straw, with added molasses and highly cellulolytic microbes [1], which were isolated from SMS [2,3]. The silage exhibited favorable ensiling characteristics and had a higher degradability of dry matter $(\mathrm{DM})$ and crude protein $(\mathrm{CP})$ than do rice straw or rye straw [1].

\footnotetext{
* Correspondence: wsk@kku.ac.kr

HRC, Division of Food Biosciences, College of Health and Medical Life Sciences, Konkuk University, Chung-Ju, Chung-Buk 380-701, Korea
}

Despite the fact that feeding BF-based silage as a roughage source to growing or fattening beef steers improved the intakes of DM and neutral detergent fiber (NDF) [4-6]. However, to our knowledge, it is unknown how rumen fermentation parameters, nutrient digestion, and $\mathrm{N}$ retention are affected by feeding BF-based silage in ruminants. Therefore, this study was performed to determine the effect of replacing rye straw (a conventional roughage source) with BF-based silage on ruminal parameters, total-tract apparent nutrient digestibility, and $\mathrm{N}$ balance in sheep.

\section{Methods \\ Manufacture of BF-based silage}

The SMS was collected fresh from a local mushroom (Pleurotus eryngii) farm. The original mushroom substrate consisted of $70 \%$ sawdust, $15 \%$ corn cobs, and $15 \%$ rice bran. The by-product feed-based silage 
was manufactured as described in Kim et al. [1] at the experimental farm of Konkuk University located in Chung-Ju city in Chung-Buk province. The SMS (45\%) was mixed with RPB (21\%), rye straw (11\%), rice bran $(10.8 \%)$, corn taffy residue (10 \%), protected fat (1.0\%), bentonite $(0.6 \%)$, and microbial additive $(0.6 \%)$, and ensiled in two folds of polyvinyl bags that were placed in a $40-\mathrm{kg}$ capacity plastic bag for $30 \mathrm{~d}$. The microbial inoculants used in this experiment were isolated and identified previously in our laboratory [2, 3], and included Enterobacter ludwigii KU201-3, Bacillus cereus KU206-3, Bacillus subtilis KU3, Bacillus subtilis KU201-7, Saccharomyces cerevisiae, and Lactobacillus plantarum. The mixture was inoculated with the strains (each added at $0.17 \%[\mathrm{v} / \mathrm{w}]$ to ensure suppying $1 \times 10^{9} \mathrm{cfu} / \mathrm{g}$ fresh biomass). Bacillus sp. and Enterobacter sp. were cultured in plate count broth (5 g casein, $2.5 \mathrm{~g}$ yeast extract, and 1 $\mathrm{g} / \mathrm{L}$ dextrose) at $36{ }^{\circ} \mathrm{C}$ for $24 \mathrm{~h}$, Saccharomyces $s p$. was cultured in yeast malt broth (0711, Difco Laboratories Inc., Detroit, MI, USA) at $30{ }^{\circ} \mathrm{C}$ for $48 \mathrm{~h}$, and Lactobacillus sp. was cultured in MRS broth (0881, Difco Laboratories Inc.) at $36{ }^{\circ} \mathrm{C}$ for $24 \mathrm{~h}$.

\section{Animal treatment, feeding regime and experimental design}

All animal care protocols were approved by the Konkuk University Institutional Animal Care and Use Committee. Six crossbred ram lambs (a mean body weight of $55 \pm 2 \mathrm{~kg}$ ) were randomly allotted to two dietary treatments: a control diet (formulated concentrate mix + rye straw) and a treatment diet (formulated concentrate mix + BF-based silage). The chemical composition of concentrate mix, rye straw, and BF-based silage is shown in Table 1. The BF-based silage contained about 4-times higher $\mathrm{CP}$ and lower neutral detergent fiber
(NDF) than rye straw. The formulated concentrate mix was composed of $23 \%$ corn grain, $17.5 \%$ wheat bran, $14 \%$ coconut meal, $10 \%$ wheat grain, $7 \%$ palm meal, $6 \%$ rapeseed meal, $5.8 \%$ molasses, $5 \%$ distillers grain, $5 \%$ corn gluten feed, $1.5 \%$ wheat flour, $1.4 \%$ limestone, $1.3 \%$ tapioca, $1 \%$ bentonite, $0.5 \%$ dehydrate salt, 0.45 $\%$ red clay, $0.25 \%$ calcium phosphate, $0.2 \%$ calcium sulfate, and $0.1 \%$ vitamin-mineral premix. Ingredients and chemical composition of diets fed to sheep are shown in Table 2. Control or treated diet was fed in equal portions in the amount of $850 \mathrm{~g}$ dry matter (DM, approximately $1.5 \%$ of body weight) at 07:00 and 18:00 h. The amount of diet DM corresponded to the requirements of growing ram lambs [7].

During the experiment, sheep always had free access to fresh water. Diets were randomly assigned to sheep at the start of the trial provided that sheep would not receive the same diet in two consecutive trials. The experiment consisted of $5 \mathrm{~d}$ transition, $10 \mathrm{~d}$ preliminary, and $7 \mathrm{~d}$ collection periods. The number of observations per treatment was 6. During the experiment, the animals were kept in individual metabolism crate $(1.6 \mathrm{~m} \times 0.5 \mathrm{~m})$ that permitted separate collection of feces and urine. Daily fecal output during the collection period was dried at $60{ }^{\circ} \mathrm{C}$. Feces were thoroughly mixed at the end of the collection period to obtain a composited sample, which was subsequently ground through a $2 \mathrm{~mm}$ screen prior to storage. Daily urine output was collected in plastic bottles containing 15 $\mathrm{ml}$ of $13.5 \mathrm{~N} \mathrm{H}_{2} \mathrm{SO}_{4}$. After weighing, $2 \%$ of the urine volume was refrigerated and bulked for the collection period.

On the last day of the experiment (d 7), 2 hours after the morning feeding, rumen fluid $(250 \mathrm{ml})$ was collected with a stomach tube using an electric

Table 1 Chemical compositions of feedstuffs fed to sheep ${ }^{1)}$

\begin{tabular}{lccc}
\hline Item & Concentrate mix (\%) & Rye straw (\%) & ${\text { BF-based silage }{ }^{2)}(\%)}^{\text {(\%) }}$ \\
\hline Dry matter & 87.9 & 90.0 & 58.3 \\
Organic matter & 91.7 & 95.4 & 88.5 \\
Crude protein & 16.4 & 4.2 & 16.9 \\
Ether extract & 2.5 & 0.2 & 3.9 \\
Neutral detergent fiber & 32.7 & 67.7 & 50.6 \\
Acid detergent fiber & 19.5 & 41.7 & 38.9 \\
Hemicellulose & 13.2 & 25.9 & 11.7 \\
Crude fiber & 11.3 & 37.8 & 31.2 \\
Nitrogen free extracts & 61.5 & 53.3 & 36.6 \\
Crude ash & 8.3 & 4.6 & 11.5 \\
\hline
\end{tabular}

${ }^{1)}$ On a dry matter basis

${ }^{2)}$ BF-based silage was by-product feed-based silage, which was composed of $45 \%$ spent mushroom substrate, $21 \%$ recycled poultry bedding, $11 \%$ rye straw, $10.8 \%$ rice bran, $10 \%$ corn taffy residue, $1.0 \%$ protected fat, $0.6 \%$ bentonite, and $0.6 \%$ microbial additive, and ensiled for $30 \mathrm{~d}$ 
Table 2 Ingredients and chemical composition of diets fed to sheep ${ }^{1)}$

\begin{tabular}{lcc}
\hline Item & Diet with & \\
\cline { 2 - 3 } & Rye straw & BF-based silage ${ }^{2)}$ \\
\hline Ingredient composition (\%) & 60.0 & 60.0 \\
Concentrate mix & 40.0 & - \\
Rye straw & - & 40.0 \\
BF-based silage & & \\
Chemical composition (\%) & 88.7 & 76.1 \\
Dry matter & 93.2 & 90.4 \\
Organic matter & 11.5 & 16.6 \\
Crude protein & 1.6 & 3.1 \\
Ether extract & 46.7 & 39.9 \\
Neutral detergent fiber & 28.4 & 27.3 \\
Acid detergent fiber & 18.3 & 12.6 \\
Hemicellulose & 21.9 & 19.2 \\
Crude fiber & 58.2 & 51.5 \\
Nitrogen-free extracts & 6.8 & 9.6 \\
Crude ash & &
\end{tabular}

${ }^{1)}$ On a dry matter basis

${ }^{2)} \mathrm{BF}$-based silage was by-product feed-based silage, which was composed of $45 \%$ spent mushroom substrate, $21 \%$ recycled poultry bedding, $11 \%$ rye straw, $10.8 \%$ rice bran, $10 \%$ corn taffy residue, $1.0 \%$ protected fat, $0.6 \%$ bentonite, and $0.6 \%$ microbial additive, and ensiled for $30 \mathrm{~d}$

vacuum pump. The fluid was strained through four layers of cheesecloth prior to the determination of $\mathrm{pH}$ (HI9321, Hanna Instrument, Portugal). Each $5 \mathrm{ml}$ of fluid was transferred to a tube containing two drops of concentrated $\mathrm{H}_{2} \mathrm{SO}_{4}$ and another $5 \mathrm{ml}$ to a tube containing $1 \mathrm{ml}$ of $25 \%(\mathrm{w} / \mathrm{v})$ of metaphosphoric acid plus $5 \mathrm{ml}$ isocaproic acid for the determination of $\mathrm{NH}_{3}-\mathrm{N}$ and volatile fatty acids (VFA), respectively.

\section{Chemical analysis}

Representative samples of the test feeds that supplied to the sheep were collected and stored at $-20{ }^{\circ} \mathrm{C}$. Immediately before the analysis, all the samples were dried and ground to pass through a 1-mm filter using a sample mill (Cemotec, Tecator, Sweden). The DM fraction was quantified by drying the samples at $60^{\circ} \mathrm{C}$ for $48 \mathrm{~h}$ until constant weight. The $\mathrm{CP}$, ether extract (EE), and crude ash contents were determined by the AOAC method [8]. Neutral detergent fiber (NDF, heat-stable $\alpha$-amylase), acid detergent fiber (ADF) were determined using the method of Van Soest et al. [9]. Ruminal $\mathrm{NH}_{3}-\mathrm{N}$ was determined according to Chaney and Marbach [10]. Ruminal VFA was determined according to Erwin et al. [11] using a Trace GC Ultra gas chromatograph (Trace GC ultra, Thermo, Italy).

\section{Statistical analysis}

Data were analyzed as a completely randomized design and subjected to one-way analysis of variance (ANOVA) using the general linear model procedure. Means separation was performed using $t$-test (Statistix7, 2000) [12] and significance was declared at $p \leq$ 0.05 . Data are presented as least squares means and standard errors of the means.

\section{Results and discussion}

Ruminal fermentation parameters

Ruminal parameters of sheep fed the different diets is shown in Table 3. The ruminal $\mathrm{pH}$ of both treatments was 6.6. Ruminal pH above 6.2 means adequate rumen fermentation [13]. Additionally, feeding BF-based silage did not affect ruminal acetate, propionate, and butyrate concentrations, and acetate: propionate ratio in sheep, but increased ruminal $\mathrm{NH}_{3}-\mathrm{N}(p<0.05)$. The $\mathrm{NH}_{3}-\mathrm{N}$ is used as a nitrogen source by ruminal microbes which can degrade both nonstructural and structural carbohydrates [14]. It was found that BF-based silage had a higher non-protein nitrogen portion than that of rye straw [1]. In the present study, feeding BF-based silage increased dietary CP intake by $44 \%$, resulting in $71 \%$ higher ruminal $\mathrm{NH}_{3}-\mathrm{N}$ concentration. Adequate ruminal $\mathrm{NH}_{3}-\mathrm{N}$ concentrations for ruminal microbial synthesis were in $5 \sim 23 \mathrm{mg} / \mathrm{dl}[15,16]$. The ruminal $\mathrm{NH}_{3}-\mathrm{N}$ concentration for the treated group were in the upper normal range. The increased ruminal $\mathrm{NH}_{3}-\mathrm{N}$ could increase ruminal VFA concentration [17], but feeding BF-based silage in the present study did not affect ruminal VFA concentrations.

Table 3 Ruminal parameters of sheep fed the different diets ${ }^{1)}$

\begin{tabular}{lccc}
\hline Item & Diet with & & SE \\
\cline { 2 - 3 } & Rye straw & BF-based silage ${ }^{2)}$ & \\
\hline Ruminal pH & 6.6 & 6.6 & 0.1 \\
Ruminal VFA (mM/l) & & & \\
Acetate & 105.6 & 107.5 & 16.1 \\
Propionate & 16.9 & 22.9 & 3.0 \\
Butyrate & 4.5 & 4.7 & 1.1 \\
Acetate/propionate & 5.9 & 4.7 & 0.7 \\
$\mathrm{NH}_{3}-\mathrm{N}$ (mg/dl) & $13.2^{\mathrm{a}}$ & $22.6^{\mathrm{b}}$ & 1.0 \\
\hline
\end{tabular}

${ }^{1)}$ Means of 6 observations

2) BF-based silage was by-product feed-based silage, which was composed of $45 \%$ spent mushroom substrate, $21 \%$ recycled poultry bedding, $11 \%$ rye straw, $10.8 \%$ rice bran, $10 \%$ corn taffy residue, $1.0 \%$ protected fat, $0.6 \%$ bentonite, and $0.6 \%$ microbial additive, and ensiled for $30 \mathrm{~d}$

a,b Means with different superscripts within the same row are significantly different $(p<0.05)$ 
Table 4 Total feed and nutrient intake by sheep fed different diets

\begin{tabular}{|c|c|c|c|}
\hline \multirow[t]{2}{*}{ Item } & \multicolumn{2}{|l|}{ Diet with } & $S$ \\
\hline & Rye straw & BF-based silage & \\
\hline \multicolumn{4}{|l|}{ Intake $(g / d)^{1)}$} \\
\hline Dry matter & 850.0 & 850.0 & 0 \\
\hline Organic matter & $792.2^{\mathrm{a}}$ & $768.7^{\mathrm{b}}$ & \\
\hline Crude protein & $97.9^{\mathrm{a}}$ & $141.3^{b}$ & \\
\hline Ether extract & $13.5^{\mathrm{a}}$ & $26.1^{\mathrm{b}}$ & \\
\hline Neutral detergent fiber & $397.0^{a}$ & $338.8^{\mathrm{b}}$ & \\
\hline Acid detergent fiber & $241.6^{\mathrm{a}}$ & $232.0^{\mathrm{b}}$ & \\
\hline Hemicellulose & $155.4^{\mathrm{a}}$ & $106.8^{\mathrm{b}}$ & \\
\hline Crude fiber & $185.9^{\mathrm{a}}$ & $163.4^{b}$ & \\
\hline Nitrogen free extracts & $494.8^{\mathrm{a}}$ & $437.8^{b}$ & \\
\hline Crude ash & $57.8^{\mathrm{a}}$ & $81.3^{\mathrm{b}}$ & \\
\hline \multicolumn{4}{|c|}{$\begin{array}{l}\text { 1) On a dry matter basis } \\
\text { 2) BF-based silage was by-product feed-based silage, which was composed of } \\
45 \% \text { spent mushroom substrate, } 21 \% \text { recycled poultry bedding, } 11 \% \text { rye } \\
\text { straw, } 10.8 \% \text { rice bran, } 10 \% \text { corn taffy residue, } 1.0 \% \text { protected fat, } 0.6 \% \\
\text { bentonite, and } 0.6 \% \text { microbial additive, and ensiled for } 30 \mathrm{~d} \\
\text { a,b Means with different superscripts within the same row are significantly } \\
\text { different ( } p<0.05 \text { ) }\end{array}$} \\
\hline
\end{tabular}

\section{Nutrients intake and digestibility}

The total feed intake are shown in Table 4. Compared to feeding rye straw, feeding BF-based silage increased $\mathrm{CP}, \mathrm{EE}$, and crude ash intake $(p<0.05)$, but decreased fiber (NDF, ADF and CF), OM, and nitrogen free extracts $(\mathrm{NFE})$ intake $(p<0.05)$. Apparent nutrient digestibility and digestible nutrient intake are shown in Table 5. Digestible CP and EE intakes increased and digestible DM, OM, fiber (NDF, ADF, and CF), and NFE intakes decreased by replacing rye straw with BF-based silage $(p<0.05)$. Compared to control treatment, sheep fed BF-based silage were observed to have 1.8, 2.9 and 8.8 percentage units lower apparent digestibility of DM, NDF, and crude ash, respectively $(p<0.05)$. It appeared that about 2-fold increase in EE intake induced increased EE digestibility. The decreased DM digestibility by feeding BF-based silage was attributed to the high ash content in BF-based silage. The decreased fiber (NDF, ADF, and crude fiber) digestibility was attributed to the high lignin content in the sawdust-based mushroom substrate included in the BF-based silage [1]. It seems natural that fiber in sawdust and corn cobs constituting major source in the SMS and BF-based silage would be less digested than that in rye straw. Calculated total digestible nutrients (TDN) of both diets did not alter, indicating that BF-based silage was equivalent to rye straw in energy value for sheep. In detail, TDN content of BF-based silage was estimated to be $44.1 \%$ when TDN content of commercial concentrate mix was assumed to be normally $79.0 \%$.
Table 5 Digestible nutrient intake and apparent nutrient digestibility of different diets fed to sheep ${ }^{1), 2)}$

\begin{tabular}{|c|c|c|c|}
\hline \multirow[t]{2}{*}{ Item } & \multicolumn{2}{|l|}{ Diet with } & \multirow[t]{2}{*}{ SE } \\
\hline & Rye straw & BF-based silage $^{3)}$ & \\
\hline \multicolumn{4}{|l|}{ Digestible nutrient intake(g/d) } \\
\hline Dry matter & $575.3^{\mathrm{a}}$ & $560.1^{b}$ & 6.3 \\
\hline Organic matter & $553.7^{\mathrm{a}}$ & $536.7^{b}$ & 5.8 \\
\hline Crude protein & $67.4^{\mathrm{a}}$ & $99.1^{b}$ & 1.1 \\
\hline Ether extract & $10.4^{\mathrm{a}}$ & $23.3^{b}$ & 0.6 \\
\hline Neutral detergent fiber & $223.0^{\mathrm{a}}$ & $180.5^{b}$ & 4.1 \\
\hline Acid detergent fiber & $124.7^{\mathrm{a}}$ & $113.2^{b}$ & 3.5 \\
\hline Hemicellulose & $98.4^{\mathrm{a}}$ & $67.3^{b}$ & 1.4 \\
\hline Crude fiber & $91.0^{\mathrm{a}}$ & $74.7^{\mathrm{b}}$ & 2.3 \\
\hline Nitrogen free extracts & $384.9^{\mathrm{a}}$ & $339.7^{b}$ & 3.6 \\
\hline Crude ash & 21.6 & 23.3 & 2.2 \\
\hline \multicolumn{4}{|l|}{ Apparent digestibility (\%) } \\
\hline Dry matter & $67.7^{\mathrm{a}}$ & $65.9^{\mathrm{b}}$ & 0.8 \\
\hline Organic matter & 69.9 & 69.8 & 0.7 \\
\hline Crude protein & 68.8 & 70.1 & 0.9 \\
\hline Ether extract & $76.8^{\mathrm{a}}$ & $89.2^{b}$ & 2.8 \\
\hline Neutral detergent fiber & $56.2^{\mathrm{a}}$ & $53.3^{b}$ & 1.1 \\
\hline Acid detergent fiber & 51.6 & 48.8 & 1.5 \\
\hline Hemicellulose & 63.3 & 63.0 & 1.1 \\
\hline Crude fiber & $48.9^{\mathrm{a}}$ & $45.7^{b}$ & 1.3 \\
\hline Nitrogen free extracts & 77.8 & 77.6 & 0.8 \\
\hline Crude ash & $37.5^{\mathrm{a}}$ & $28.7^{b}$ & 2.7 \\
\hline Total digestible nutrients (\%) & 66.7 & 66.6 & 0.7 \\
\hline
\end{tabular}

${ }^{1)}$ On a dry matter basis

${ }^{2)}$ Means of 6 observations

${ }^{3)}$ By-product feed-based silage

${ }^{\mathrm{a}, \mathrm{b}}$ Means with different superscripts within the same row are significantly different $(p<0.05)$

\section{Nitrogen balance}

The $\mathrm{N}$ balance of sheep fed the different diets is shown in Table 6. Because of the CP content difference between rye straw (4.2\%) and BF-based silage (16.9 \%), $\mathrm{N}$ intake significantly increased $6.9 \mathrm{~g} / \mathrm{d}$ by feeding BF-based silage $(p<0.05)$. Feeding BF-based silage increased $\mathrm{N}$ excretion, absorption and retention by $6,5.1$, and $0.9 \mathrm{~g} / \mathrm{d}(p<0.05)$, respectively. But $\mathrm{N}$ retention, expressed \% intake or \% absorbed, was not different between rye straw and BF-based silage, indicating that $\mathrm{N}$ retention efficiency was similar between rye straw $\mathrm{N}$ and BF-based silage $\mathrm{N}$. Normally with dietary $\mathrm{N}$ intake increased, $\mathrm{N}$ absorption and total $\mathrm{N}$ excretion were increased [18] as shown in this study. The high ruminal $\mathrm{NH}_{3}-\mathrm{N}$ could be available mostly as a nitrogen source for ruminal microbial growth, but excessive $\mathrm{NH}_{3}-\mathrm{N}$ would be absorbed through the 
Table 6 Nitrogen balance of sheep fed the different diets ${ }^{1)}$

\begin{tabular}{lccc}
\hline Item & Diet with & & SE \\
\cline { 2 - 3 } & Rye straw & BF-based silage ${ }^{2)}$ & \\
\hline Intake $(\mathrm{g} / \mathrm{d})$ & $15.7^{\mathrm{a}}$ & $22.6^{\mathrm{b}}$ & 0.1 \\
Excretion (g/d) & & & \\
Fecal & $4.9^{\mathrm{a}}$ & $6.8^{\mathrm{b}}$ & 0.2 \\
Urinary & $7.9^{\mathrm{a}}$ & $12.1^{\mathrm{b}}$ & 0.2 \\
Total & $12.8^{\mathrm{a}}$ & $18.8^{\mathrm{b}}$ & 0.3 \\
Absorption (g/d) & $10.8^{\mathrm{a}}$ & $15.9^{\mathrm{b}}$ & 0.2 \\
Retention & & & \\
g/d & $2.9^{\mathrm{a}}$ & $3.8^{\mathrm{b}}$ & 0.3 \\
\% intake & 18.4 & 16.8 & 1.6 \\
\% absorbed & 26.7 & 24.0 & 2.1 \\
\hline Means of 6 obsation
\end{tabular}

${ }^{1)}$ Means of 6 observations

${ }^{2)} \mathrm{BF}$-basedsilage was by-product feed-based silage, which was composed of 45 $\%$ spent mushroom substrate, $21 \%$ recycled poultry bedding, $11 \%$ rye straw, $10.8 \%$ rice bran, $10 \%$ corn taffy residue, $1.0 \%$ protected fat, $0.6 \%$ bentonite, and $0.6 \%$ microbial additive, and ensiled for $30 \mathrm{~d}$ $a, b$ Means with different superscripts within the same row are significantly different $(p<0.05)$

rumen wall or flow into the lower digestive tract and further absorbed, resulting in increased $\mathrm{N}$ retention for the BF-based silage-fed sheep.

\section{Conclusions}

The present results indicate that BF-based silage showed low fiber digestion and high $\mathrm{N}$ retention by sheep compared to rye straw. The BF-based silage had similar energy value to rye straw. These characteristics of BF-based silage could be used as basic data for total mixed ration formulation in ruminants. Using BF-based silage could help reduce feed cost in many countries importing hays.

\section{Competing interests}

The authors declare that they have no competing interests.

\section{Authors' contributions}

JS made the experimental design and detailed chemical and statistical analysis of the study. YI drafted the manuscript. YH assisted the manuscript writing and standard form of the journal, and DY performed the statistical analysis. WS made substantial contributions to the study conception and design, and revised the manuscript as the corresponding author.

\section{Acknowledgements}

This study was carried out with the support of the "Cooperative Research Program for Agriculture Science and Technology Development (Project No. PJ009382012015)", the Rural Development Administration, Republic of Korea. Also, this paper was written as part of Konkuk University's research support program for its faculty on sabbatical leave in 2014.

\section{Received: 4 June 2015 Accepted: 25 January 2016}

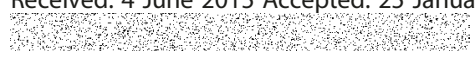

\section{References}

1. Kim YI, Oh YK, Park KK, Kwak WS. Ensiling characteristics and the in situ nutrient degradability of a by-product feed-based silage. Asian-Aust J Anim Sci. 2014;27:201-8.
2. Kim YI, Jung SH, Seok JS, Yang SY, Huh JW, Kwak WS. Isolation and identification of high cellulolytic bacteria from spent mushroom substrate and determination of optimal medium conditions for the growth. Kor J Microbial Biotechnol. 2007;3:255-60.

3. Kim YI, Jeong SH, Seok JS, Yang SY, Huh JW, Kwak WS. Isolation and identification of hydrolytic enzyme-producing bacteria from spent mushroom substrate. Korean J Anim Sci Technol. 2008;50:713-20.

4. Kim YI, Lee SM, Lee YH, Lee M, Choi DW, Kwak WS. Effects of by-product feed-based silage on feeding, rumination, and excretion in growing Hanwoo heifers. Korean J Anim Sci Technol. 2015;57:3.

5. Kim Yl, Lee SM, Park KK, Kwak WS. Effect of feeding by-product feeds-based silage (Biosilage) on behavior pattern of growing Hanwoo steers. J Kor Grassl Forage Sci. 2013;33:290-7.

6. Kim YI, Park JM, Lee YH, Lee M, Choi DY, Kwak WS. Effect of by-product feed-based silage feeding on the performance, blood Metabolites, and carcass characteristics of Hanwoo steers (a field study). Asian-Aust J Anim Sci. 2015;2:180-7.

7. NRC. Nutrient requirements of sheep. Washington, DC: National Academy Press; 1985.

8. AOAC (Association of Official Analytical Chemists). Official methods of analysis. 17th ed. Washington DC: Association of Analytical Chemists; 2000.

9. Van Soest PJ, Robertson JB, Lewis BA. Methods of dietary fiber, neutral detergent fiber, nonstarch polysaccharides in relation to animal nutrition. J Dairy Sci. 1991;74:3583-97.

10. Chaney AL, Marbach EP. Modified reagents for the determination of urea. Clin Chem. 1962:8:130-2.

11. Erwin ES, Naro GJ, Emery EM. Volatile fatty acid analysis of blood and rumen fluid by gas chromatography. J Dairy Sci. 1961;44:1768.

12. Statistix7: User's manual. Analytical Software, Tallagassee, FL, USA; 2000.

13. Russell JB, Schcarp WM, Baldwin RL. The effect of $\mathrm{pH}$ on maximum bacterial growth rate and of bacterial competition in the rumen. J Anim Sci. 1979;48:251.

14. Satter LD, Slyter LL. Effect of ammonia concentration on rumen microbial protein production in vitro. Br J Nutr. 1974;32:199.

15. Mehrez AZ, Orskov ER, McDonald I. Rates of rumen fermentation in relation to ammonia concentration. Br J Nutr. 1977;8:447.

16. Haaland GL, Tyrrell HF, Moe PW, Wheeler WE. Effect of crude protein level and limestone buffer in diets fed at two levels of intake on rumen $\mathrm{pH}$, ammonia-nitrogen, buffering capacity and volatile fatty acid concentration of cattle. J Anim Sci. 1982;55:943-50.

17. Kwak WS, Yoon JS, Jung KK. Nutrient utilization of broiler litter and bakery by-product ration in Sheep. J Anim Sci Technol. 2003;4:607-16.

18. Ko YD, Ryu YU, Kang HS, Kim JH, Yoo SO, Kang KR. Study on the digestibility, nitrogen retention and rumen parameters in sheep fed whole crop corn-cage layer excreta silage I. Nutrition quality, digestibility and nitrogen retention of the whole crop corn-cage layer excreta. Kor J Anim Nutr Feed. 1996;20:453-8.

Submit your next manuscript to BioMed Central and we will help you at every step:

- We accept pre-submission inquiries

- Our selector tool helps you to find the most relevant journal

- We provide round the clock customer support

- Convenient online submission

- Thorough peer review

- Inclusion in PubMed and all major indexing services

- Maximum visibility for your research

Submit your manuscript at www.biomedcentral.com/submit 